\title{
Pengaruh Perbandingan Bahand Pelarut dan Lama Ekstraksi terhadap Karakteristik Ekstrak Pewarna Daun Pandan Wangi (Pandanus amaryllifolius Roxb.)
}

\author{
I Made Dwipayana, Ni Made Wartini*, Luh Putu Wrasiati \\ PS Teknologi Industri Pertanian, Fakultas Teknologi Pertanian, Universitas Udayana, Kampus Bukit \\ Jimbaran, Badung, Kode pos : 80361; Telp/Fax : (0361) 701801.
}

Diterima 29 Juli 2019 / Disetujui 16 Agustus 2019

\begin{abstract}
Dyes from fragrant pandan leaves contain chlorophyll obtained through the extraction process. The purpose of this study were to determine the effect of the ratio of ingredients to solvents and the length of extraction on the characteristics of natural coloring extracts of fragrant pandan leaves and determine the best treatment from the comparison of ingredients with solvents and extraction time to produce natural coloring extracts of fragrant pandan leaves. This study used a 2 factor factorial randomized block design. The first factor is the comparison of materials with solvents consisting of 3 levels, namely 1:13, 1:15, and 1:17. The results showed that the comparative treatment of the material with the solvent and the extraction time greatly influenced the extract yield, chlorophyll a levels, chlorophyll b levels, total chlorophyll levels, brightness level $L *$, redness level $a *$, yellowish level $b *$, interactions greatly influenced the levels chlorophyll a, chlorophyll b level, total chlorophyll content, redness level $(a *)$, yellowish level $(b *)$ but have no effect on extract yield and brightness level $(L *)$. Comparison of material treatment with solvent 1:15 and extraction time for 36 hours, is the best treatment to produce pandanus fragrant leaf extract coloring with extract yield characteristics of $10.32 \%$, chlorophyll a levels of 3402.04 ppm, chlorophyll b levels of 612.23 ppm, total chlorophyll content of 4013.42 ppm, brightness level $(L *) 35.27$, redness level $(a *) 17.15$, yellowish level $(b *) 30.43$.
\end{abstract}

Keywords: Pandanus amaryllifolius Roxb., chlorophyll, nature color, extraction.

*Korespondensi Penulis:

Email : md_wartini@unud.ac.id 


\section{PENDAHULUAN}

Daun pandan wangi (Pandanus amaryllifolius Roxb.) atau biasa disebut pandan saja adalah daun yang memiliki warna hijau alami, warna hijau ini disebabkan oleh pigmen klorofil (Dalimarta, 1999). Daun pandan wangi berpotensi sebagai pewarna alami pada makanan. Warna merupakan salah satu parameter selain cita rasa, tekstur dan nilai nutrisi yang menentukan persepsi konsumen terhadap suatu bahan pangan. Dewasa ini keamanan penggunaan zat pewarna sintetis pada makanan masih dipertanyakan dikalangan konsumen karena berbahaya. Zat pewarna alami lebih baik daripada pewarna sintetis karena zat pewarna alami lebih aman dikonsumsi dan dapat menambah nilai gizi pada makanan yang bermanfaat bagi tubuh. Sedangkan zat warna sintesis apabila dikonsumsi secara terusmenerus dapat berpotensi sebagai sumber kanker (Reysa, 2016). Tanaman ini biasanya tumbuh di daerah tropis dan banyak ditanam dihalaman rumah, kebun-kebun ataupun di sawah-sawah (Margaretta et al., 2011). Pemanfaatan daun pandan wangi sebagai zat pewarna dapat dilakukan dengan cara ekstraksi. Ekstraksi adalah proses pemisahan suatu bahan dari campurannya. Proses ekstraksi dihentikan ketika tercapainya kesetimbangan antara bahan dengan pelarut terhadap ekstrak yang dihasilkan (Mukhriani, 2014).

Beberapa faktor yang mempengaruhi proses ekstraksi diantaranya adalah perbandingan bahan dengan pelarut dan lama ekstraksi. Pada penelitian Hernes et al. (2018) mengenai ekstraksi klorofil dari Sargassum polycystum menunjukkan bahwa ekstrak kadar klorofil tertinggi didapat pada perbandingan bahan dengan pelarut $(1: 15)$ dibandingkan dengan perlakuan perbandingan bahan dengan pelarut (1:9), (1:11), (1:13), dan (1:17). Penelitian Pratista et al. (2017) yang meneliti tentang ekstraksi pewarna alami pada Sargassum polycystum dengan perlakuan lama maserasi 12, 24, 36 jam menunjukkan perlakuan terbaik pada waktu maserasi 36 jam. Selama ini penelitian mengenai pengaruh perbandingan bahan dengan pelarut dan lama ekstraksi pewarna daun pandan wangi belum pernah dilakukan. Warna daun pandan wangi termasuk dalam golongan klorofil dan harus diekstraksi dengan pelarut yang mempunyai polaritas sesuai dan jumlah yang tepat. Perbandingan bahan dengan pelarut berpengaruh terhadap proses ekstraksi karena semakin banyak pelarut yang digunakan maka semakin banyak senyawa yang dapat diekstrak sampai pada batas tertentu senyawa yang diekstrak habis dalam bahan.

Tujuan penelitian ini adalah untuk mengetahui pengaruh perbandingan bahan dengan pelarut dan lama ekstraksi terhadap karakteristik ekstrak pewarna alami daun pandan serta menentukan perbandingan bahan dengan pelarut dan lama ekstraksi terbaik untuk menghasilkan ekstrak pewarna daun pandan wangi.

\section{METODE PENELITIAN}

\section{Tempat dan Waktu}

Penelitian ini dilakukan di Laboratorium Pengolahan Pangan, Laboratorium Analisis Pangan dan Laboratorium Rekayasa Proses dan Pengendalian Mutu Fakultas Teknologi Pertanian Universitas Udayana. Penelitian ini dilakukan pada Maret sampai dengan Mei 2019.

\section{Alat dan Bahan}

Peralatan yang digunakan dalam penelitian ini antara oven pengering (Blue M OV-520C-2), ayakan 40 mesh (Retsch), blender (Philips), gelas ukur (Herma, Iwaki), botol sampel, panci, pisau, thermometer (TP101), kertas saring kasar, kertas saring 
Whatman No. 1, rotary evaporator (Janke \& Kunkel RV 06 - ML), pipet volume, tabung reaksi (Iwaki), timbangan analitik (Mattler Toledo AB 204), pipet tetes, beaker glass, color reader (Accuprobe HH-06), spektrofotometer (Genesys 10S UV-VIS), vortex (Barnstead Thermolyne Maxi Mix II), erlenmeyer (Duran), desikator (Duran), gelas ukur, labu ukur dan kertas label.

Bahan baku yang digunakan adalah daun pandan wangi yang diperoleh dari Desa Buduk, Kecamatan Mengwi, Kabupaten Badung, Provinsi Bali dengan kriteria berwarna hijau tua, panjang 2-3 m, lebar 8-10 $\mathrm{cm}$. Bahn lain yang digunakan adalah aquades, pelarut teknis untuk ekstraksi yaitu aseton $85 \%$ (Bratachem). Sedangkan bahan kimia untuk analisis yaitu aseton $80 \%$ pa (Mallinckrodt).

\section{Rancangan Percobaan}

Percobaan ini merupakan percobaan faktorial 2 faktor menggunakan Rancangan Acak Kelompok (RAK). Faktor I yaitu perbandingan bahan dengan pelarut aseton (P) terdiri atas 3 taraf yaitu: $\mathrm{P} 1=1: 13, \mathrm{P} 2=$ $1: 15, \mathrm{P} 3=1: 17$ Faktor II yaitu lama ekstraksi $(\mathrm{T})$ terdiri atas 3 taraf yaitu: $\mathrm{T} 1=24$ jam, T2 = 36 jam, T3 = 48 jam. Dari 2 faktor di atas diperoleh 9 kombinasi perlakuan, masing-masing perlakuan dikelompokkan menjadi 2 berdasarkan waktu pengerjaanya sehingga diperoleh 18 unit percobaan. Data obyektif yang diperoleh diuji dengan analisis keragaman dan apabila perlakuan berpengaruh terhadap variabel yang diamati, maka dilanjutkan dengan uji lanjut Tukey 5\% menggunakan software minitab 17. Perlakuan terbaik ditentukan dengan uji indek efektivitas (De Garmo et al., 1984).

\section{Pelaksanaan Penelitian}

Daun pandan wangi dipilih dengan warna hijau tua yang seragam kemudian dicuci dengan air untuk menghilangkan sisa kotoran dan benda asing yang menempel. Selanjutnya ditimbang daun pandan wangi 600 gram kemudian dipotong dengan panjang kira-kira $30 \mathrm{~cm}$ lalu dilakukan blansir pada suhu $100{ }^{\circ} \mathrm{C}$ selama 1 menit dengan tujuan menghambat aktivitas enzim klorofilase. Selanjutnya daun pandan wangi dipotong dengan panjang $1 \mathrm{~cm}$, kemudian dilakukan pengeringan pada suhu $50 \pm 2^{\circ} \mathrm{C}$ sampai mudah dihancurkan. Daun pandan wangi yang telah kering selanjutnya dihancurkan dan diayak menggunakan ayakan 40 mesh dan hasil ayakan disimpan di dalam wadah gelap sebelum diekstraksi.

Daun pandan ditimbang seberat 25 gram kemudian ditambahkan pelarut aseton teknis dalam botol gelap volume 1 liter dengan perbandingan sesuai perlakuan yaitu $1: 13$ (25g : $325 \mathrm{ml}), 1: 15$ ( $25 \mathrm{~g}: 375 \mathrm{ml}$ ), dan $1: 17$ (25 g : $425 \mathrm{ml})$ dengan metode maserasi. Maserasi dilakukan selama 24, 36, 48 jam sesuai perlakuan pada suhu kamar 28 $\pm \quad 2^{\circ} \mathrm{C}$. Selama maserasi dilakukan penggojogan secara manual setiap 12 jam selama 5 menit. Selanjutnya ekstrak disaring menggunakan kertas saring kasar yang menghasilkan filtrat I dan ampas. Ampas ditambahkan pelarut aseton teknis $85 \%$ sebanyak $50 \mathrm{ml}$, kemudian disaring dengan kertas saring kasar sehingga menghasilkan Filtrat II. Filtrat I dan II dicampur dan disaring dengan kertas saring Whatman No. 1. Filtrat selanjutnya dievaporasi dengan rotary evaporator. Evaporasi dilakukan pada suhu $40^{\circ} \mathrm{C}$ dengan tekanan 100 mBar untuk menguapkan pelarut yang terdapat dalam ekstrak sampai semua pelarut habis menguap yang ditandai dengan pelarut tidak menetes lagi. Ekstrak kental yang diperoleh dimasukkan ke dalam botol sampel.

\section{Variabel yang Diamati}

Variabel yang diamati pada daun pandan wangi adalah rendemen ekstrak (Sudarmadji et al., 1989), kadar klorofil (Nollet, 2004) dan intensitas warna sistem 
$\mathrm{L}^{*}, \mathrm{a}^{*}, \mathrm{~b}^{*}($ Weaver, 1996)

\section{HASIL DAN PEMBAHASAN}

\section{Rendemen}

Hasil analisis keragaman menunjukkan bahwa perlakuan perbandingan bahan dengan pelarut dan lama ekstraksi berpengaruh sangat nyata $(P \leq 0,01)$, sedangkan interaksi berpengaruh tidak nyata $(\mathrm{P} \geq 0,05)$ terhadap rendemen ekstrak daun pandan wangi. Nilai rata-rata rendemen ekstrak daun pandan wangi dapat dilihat pada Tabel 1.

Tabel 1. Nilai rata-rata rendemen ekstrak daun pandan wangi (\%) pada perlakuan perbandingan bahan dengan pelarut dan lama ekstraksi.

\begin{tabular}{ccccc}
\hline Perbandingan Bahan & \multicolumn{3}{c}{ Lama Ekstraksi (jam) } & Rata-rata \\
\cline { 2 - 4 } dengan Pelarut & $24(\mathrm{~T} 1)$ & $36(\mathrm{~T} 2)$ & $48(\mathrm{~T} 3)$ & $9,04 \pm 0,19^{\mathrm{b}}$ \\
\hline $1: 13(\mathrm{P} 1)$ & $8,78 \pm 0,08$ & $9,28 \pm 0,28$ & $9,06 \pm 0,20$ & $10,07 \pm 0,50^{\text {a }}$ \\
$1: 15(\mathrm{P} 2)$ & $9,74 \pm 0,42$ & $10,32 \pm 0,62$ & $10,14 \pm 0,48$ & \\
$1: 17$ (P3) & $9,44 \pm 0,11$ & $10,06 \pm 0,42$ & $9,90 \pm 0,37$ & $9,80 \pm 0,30^{\text {a }}$ \\
\hline Rata-rata & $9,32 \pm 0,20^{\mathrm{b}}$ & $9,88 \pm 0,44^{\mathrm{a}}$ & $9,70 \pm 0,35^{\mathrm{a}}$ &
\end{tabular}

Keterangan: Huruf yang berbeda di belakang nilai rata-rata pada baris atau kolom yang sama menunjukkan adanya perbedaan yang nyata $(\mathrm{P} \leq 0,05)$. Data merupakan rata-rata dari dua kelompok percobaan.

Tabel 1 menunjukkan bahwa pada perlakuan perbandingan bahan dengan pelarut (1:15) menghasilkan rendemen ekstrak daun pandan wangi sebesar $10,07 \pm 0,50 \%$, tetapi tidak berbeda nyata dengan perlakuan (1:17). Hal ini diduga terjadi karena pelarut yang digunakan sudah mencapai titik jenuhnya yang menyebabkan rendemen ekstrak yang dihasilkan tidak mengalami kenaikan lagi pada perlakuan (1:17). Hasil tersebut didukung oleh penelitian Handayani et al. (2016) tentang ekstraksi daun sirsak yang menghasilkan rendemen ekstrak optimum pada perbandingan bahan dengan pelarut (1:15).

Lama ekstraksi juga memiliki peranan yang penting seperti halnya pengaruh perbandingan bahan dengan pelarut terhadap rendemen ekstrak yang dihasilkan. Table ini menunjukkan bahwa lama ekstraksi 36 jam yang menghasilkan rendemen ekstrak daun pandan wangi yang tidak berbeda nyata dengan lama ekstraksi 48 jam. Pada lama ekstraksi 36 jam diduga bahan sudah habis terekstrak sehingga menyebabkan rendemen yang dihasilkan tidak mengalami peningkatan lagi pada lama ekstraksi 48 jam. Hasil ini didukung oleh penelitian Pratista $e t$ al. (2017) yang meneliti tentang Sargasum polycystum menghasilkan rendemen ekstrak tertinggi pada lama maserasi 36 jam.

\section{Kadar Klorofil a}

Hasil analisis keragaman menunjukkan bahwa perbandingan bahan dengan pelarut, lama ekstraksi serta interaksi berpengaruh sangat nyata $(P \leq 0,01)$, terhadap kadar klorofil a. Nilai rata-rata dari kadar klorofil a dapat dilihat pada Tabel 2.

Tabel 2. Nilai rata-rata kadar klorofil a (ppm) pada perlakuan perbandingan bahan dengan pelarut dan lama ekstraksi.

\begin{tabular}{cccc}
\hline Perbandingan Bahan dengan & \multicolumn{3}{c}{ Lama Ekstraksi (jam) } \\
\cline { 2 - 4 } Pelarut & $24(\mathrm{~T} 1)$ & $36(\mathrm{~T} 2)$ & $48(\mathrm{~T} 3)$ \\
\hline $1: 13(\mathrm{P} 1)$ & $1422,66 \pm 2,36^{\mathrm{g}}$ & $2135,27 \pm 11,34^{\mathrm{f}}$ & $1290,32 \pm 21,32^{\mathrm{h}}$ \\
$1: 15(\mathrm{P} 2)$ & $2971,44 \pm 9,61^{\mathrm{b}}$ & $3402,04 \pm 22,27^{\mathrm{a}}$ & $2643,80 \pm 28,67^{\mathrm{d}}$ \\
$1: 17(\mathrm{P} 3)$ & $2359,93 \pm 34,65^{\mathrm{e}}$ & $2833,06 \pm 12,96^{\mathrm{c}}$ & $2084,27 \pm 28,67^{\mathrm{f}}$ \\
\hline
\end{tabular}


Keterangan: Huruf berbeda di belakang nilai yang sama menunjukkan perbedaan yang sangat nyata $(\mathrm{P} \leq 0,01)$. Data merupakan rata-rata dari dua kelompok.

Tabel 2 menunjukkan bahwa perbandingan bahan dengan pelarut 1:15 dan lama ekstraksi 36 jam menghasilkan kadar klorofil a tertinggi, yaitu sebesar $3402,04 \pm 22,27 \mathrm{ppm}$. Hasil ini menunjukan bahwa semakin besar perbandingan bahan dengan pelarut dan semakin lama ekstraksi maka semakin banyak kadar klorofil a yang dihasilkan. Pada perbandingan bahan dengan pelarut (1:15) dan lama ekstraksi 36 jam, pelarut sudah mencapai titik jenuhnya dikarenakan kadar klorofil yang dapat terekstrak sudah maksimal, akibatnya perlakuan (1:17) dan lama ekstraksi 48 jam kadar klorofil kemungkinan mengalami kerusakan dan mudah teroksidasi sehingga menyebabkan kandungan klorofil menjadi turun.

Hasil ini didukung oleh penelitian Putri et al. (2012) menyatakan rasio bahan dengan pelarut yang terlalu tinggi akan menyebabkan pelarut akan teroksidasi sehingga memberikan pengaruh kerusakan klorofil dengan membentuk feofitin. Menurut Aronoff (1958) bahwa klorofil a tidak stabil terhadap panas dan lebih cepat menjadi feofitin. Hasil ini juga dukung oleh penelitian Pratista et al. (2017) tentang ekstraksi Sargasum polycystum yang menghasilkan kadar klorofil a tertinggi pada lama maserasi 36 jam.

\section{Kadar Klorofil b}

Hasil analisis keragaman menunjukkan bahwa perbandingan bahan dengan pelarut, lama ekstraksi serta interaksi berpengaruh sangat nyata $(P \leq 0,01)$, terhadap kadar klorofil b. Nilai rata-rata dari kadar klorofil a dapat dilihat pada Tabel 3.

Tabel 3. Nilai rata-rata kadar klorofil b (ppm) pada perlakuan perbandingan bahan dengan pelarut dan lama ekstraksi.

\begin{tabular}{cccc}
\hline Perbandingan Bahan dengan & \multicolumn{3}{c}{ Lama Ekstraksi (jam) } \\
\cline { 2 - 4 } Pelarut & $24(\mathrm{~T} 1)$ & $36(\mathrm{~T} 2)$ & $48(\mathrm{~T} 3)$ \\
\hline $1: 13(\mathrm{P} 1)$ & $180,48 \pm 4,29^{\mathrm{cd}}$ & $268,42 \pm 0,99^{\mathrm{c}}$ & $143,44 \pm 25,71^{\mathrm{de}}$ \\
$1: 15(\mathrm{P} 2)$ & $442,28 \pm 8,71^{\mathrm{b}}$ & $612,23 \pm 17,61^{\mathrm{a}}$ & $559,36 \pm 0,24^{\mathrm{a}}$ \\
$1: 17$ (P3) & $79,73 \pm 2,44^{\mathrm{e}}$ & $361,82 \pm 61,58^{\mathrm{b}}$ & $254,35 \pm 0,24 \mathrm{c}$ \\
\hline
\end{tabular}

Keterangan: Huruf berbeda di belakang nilai rata-rata menunjukkan perbedaan yang sangat nyata $(\mathrm{P} \leq 0,01)$. Data merupakan rata-rata dari dua kelompok.

Tabel 3 menunjukkan bahwa pada perlakuan perbandingan bahan dengan pelarut (1:15) dan lama ekstraksi 36 jam menghasilkan klorofil b ektrak daun pandan wangi tertinggi, tetapi tidak berbeda nyata dengan perlakuan (1:15) dengan lama ekstraksi 48 jam. Hasil ini menunjukkan bahwa semakin besar perbandingan bahan dengan pelarut dan semakin lama ekstraksi maka semakin banyak kadar klorofil b yang dihasilkan ekstrak pewarna alami daun pandan wangi. Pada perbandingan bahan dengan pelarut (1:15) dan lama ekstraksi 36 jam kadar klorofil yang terekstrak sudah optimal, kemudian turun pada perlakuan (1:17) dan lama ekstraksi 48 jam. Hal tersebut kemungkinan klorofil mengalami kerusakan karena teroksidasi akibatnya kadar klorofil menjadi turun. Hasil tersebut di dukung oleh penelitian Hernes et al. (2016) yang meneliti tentang Sargasum polycystum dengan menghasilkan kadar klorofil b tertinggi pada perbandingan bahan dengan pelarut (1:15). Hasil ini juga didukung olreh penelitian Pratista et al. (2017) tentang ekstraksi Sargasum polycystum yang menghasilkan kadar klorofil $b$ tertinggi pada lama maserasi 36 jam. 


\section{Kadar Klorofil Total}

Hasil analisis keragaman menunjukkan bahwa perbandingan bahan dengan pelarut dan lama ekstraksi serta interaksi berpengaruh sangat nyata $(\mathrm{P} \leq 0,01)$ terhadap kadar klorofil total. Nilai rata-rata dari kadar klorofil total dapat dilihat pada Tabel 4.

Tabel 4. Nilai rata-rata kadar total klorofil (ppm) pada perlakuan perbandingan bahan dengan pelarut dan lama ekstraksi.

\begin{tabular}{cccc}
\hline Perbandingan Bahan dengan & \multicolumn{3}{c}{ Lama Ekstraksi (jam) } \\
\cline { 2 - 4 } Pelarut & $24(\mathrm{~T} 1)$ & $36(\mathrm{~T} 2)$ & $48(\mathrm{~T} 3)$ \\
\hline $1: 13(\mathrm{P} 1)$ & $1602,81 \pm 6,65^{\mathrm{e}}$ & $2403,20 \pm 12,32^{\mathrm{d}}$ & $1433,47 \pm 47,02^{\mathrm{f}}$ \\
$1: 15(\mathrm{P} 2)$ & $3413,01 \pm 0,91^{\mathrm{b}}$ & $4013,42 \pm 39,87^{\mathrm{a}}$ & $3202,46 \pm 28,43^{\mathrm{c}}$ \\
$1: 17(\mathrm{P} 3)$ & $2439,23 \pm 32,21^{\mathrm{d}}$ & $3194,23 \pm 48,59^{\mathrm{c}}$ & $2338,15 \pm 2843^{\mathrm{d}}$ \\
\hline
\end{tabular}

Keterangan: Huruf beda di belakang nilai rata-rata menunjukkan perbedaan yang sangat nyata $(\mathrm{P} \leq 0,01)$. Data merupakan rata-rata dari dua kelompok.

Tabel 4 menunjukkan bahwa pada perlakuan perbandingan bahan dengan pelarut (1:15) dengan lama ekstraksi 36 jam menghasilkan kadar total klorofil ekstrak daun pandan wangi yang tertinggi, yaitu sebesar 4013,42 $\pm 39,87$ ppm dan kadar klorofil total terendah pada perlakuan 1:13 dengan lama ekstraksi 48 jam, yaitu sebesar $1433,47 \pm 47,02$ ppm. Pada perbandingan bahan dengan pelarut (1:15) pelarut sudah mencapai titik jenuhnya dan lama ekstraksi 36 jam kontak antara bahan dengan pelarut sudah mencapai batas tertentu bahan habis terekstrak. Sehingga pada perlakuan (1:17) kadar klorofil kemungkinan mengalami kerusakan dan mudah teroksidasi yang menyebabkan kandungan klorofil menjadi turun. Hasil tersebut di dukung oleh penelitian Hernes et al. (2016) yang meneliti tentang Sargasum polycystum dengan menghasilkan kadar klorofil total tertinggi pada perbandingan (1:15). Penelitian Pratista et al. (2017) yang meneliti tentang Sargasum polycystum yang menghasilkan kadar klorofil total tertinggi pada lama maserasi 36 jam.

\section{Intensitas Warna $\left(\mathbf{L}^{*}, \mathbf{a}^{*}, \mathbf{b}^{*}\right)$ Tingkat kecerahan $\left(\mathrm{L}^{*}\right)$}

Hasil analisis keragaman menunjukkan bahwa perlakuan perbandingan bahan dengan pelarut dan lama ekstraksi berpengaruh sangat nyata $(P \leq 0,01)$, sedangkan interaksi berpengaruh tidak nyata $(\mathrm{P} \geq 0,05)$ terhadap tingkat kecerahan $\left(\mathrm{L}^{*}\right)$ ekstrak daun pandan wangi. Nilai $\left(\mathrm{L}^{*}\right)$ menyatakan tingkat gelap sampai terang dengan kisaran $0-100$. Nilai rata-rata dari tingkat kecerahan $\left(\mathrm{L}^{*}\right)$ dapat dilihat pada Tabel 5.

Tabel 5. Nilai rata-rata tingkat kecerahan $\left(\mathrm{L}^{*}\right)$ pada perlakuan perbandingan bahan dengan pelarutn dan lama ekstraksi.

\begin{tabular}{ccccc}
\hline Perbandingan Bahan & \multicolumn{3}{c}{ Lama Ekstraksi (jam) } & Rata-rata \\
\cline { 2 - 4 } dengan Pelarut & $24(\mathrm{~T} 1)$ & $36(\mathrm{~T} 2)$ & $48(\mathrm{~T} 3)$ & $38,70 \pm 0,31^{\mathrm{a}}$ \\
$1: 13(\mathrm{P} 1)$ & $40,01 \pm 0,32$ & $36,76 \pm 0,46$ & $39,34 \pm 0,15$ & $36,37 \pm 0,67^{\mathrm{b}}$ \\
$1: 15(\mathrm{P} 2)$ & $37,90 \pm 1,73$ & $35,27 \pm 0,06$ & $35,96 \pm 0,23$ & \\
$1: 17(\mathrm{P} 3)$ & $39,16 \pm 0,16$ & $37,65 \pm 1,46$ & $38,98 \pm 0,18$ & $38,59 \pm 0,60^{\mathrm{a}}$ \\
\hline Rata-rata & $39,02 \pm 0,73^{\mathrm{a}}$ & $36,56 \pm 0,66^{\mathrm{b}}$ & $39,29 \pm 0,18^{\mathrm{a}}$ & \\
\hline
\end{tabular}

Keterangan: Huruf yang berbeda di belakang nilai rata-rata pada baris atau kolom yang sama menunjukkan adanya perbedaan yang nyata $(\mathrm{P}<0,05)$. Data merupakan rata-rata dari dua kelompok percobaan.

Tabel 5 menunjukkan bahwa pada perlakuan perbandingan bahan dengan pelarut 1:15 menghasilkan tingkat kecerahan yang paling rendah yaitu sebesar 
36,37 $\pm 0,67$. Hal ini dikarenakan kadar klorofil yang terkandung pada ekstrak daun pandan wangi dengan perlakuan perbandingan bahan dengan pelarut $(1: 15)$ paling tinggi sehingga tingkat kecerahan yang dihasilkan semakin rendah (gelap). Hasil penelitian Manasika dan Widjanarko (2015) menunjukkan semakin banyak pigmen yang terekstrak menyebabkan warna ekstrak akan semakin gelap dan pekat, sehingga nilai kecerahan menurun.

Lama ekstraksi juga berpengaruh terhadap tingkat kecerahan ( $\left.\mathrm{L}^{*}\right)$, lama maserasi 36 jam memiliki nilai tingkat kecerahan ( $\mathrm{L}^{*}$ ) yang paling rendah dibandingkan dengan lama maserasi 24 dan 48 jam. Hal ini dikarenakan pada perlakuan lama ekstraksi 36 jam menghasilkan kadar klorofil paling tinggi sehingga nilai tingkat kecerahan ( $\left.\mathrm{L}^{*}\right)$ semakin rendah. Menurut Khuluq et al. (2007) dijelaskan bahwa kandungan pigmen yang tinggi pada bahan yang diesktrak mempengaruhi tingkat kecerahan.

\section{Tingkat kemerahan ( $\left.a^{*}\right)$}

Hasil analisis keragaman menunjukkan bahwa faktor perlakuan perbandingan bahan dengan pelarut, lama ekstraksi dan interaksi kedua perlakuan berpengaruh sangat nyata $(\mathrm{P} \leq 0,01)$ terhadap tingkat kemerahan $\left(\mathrm{a}^{*}\right)$ ekstrak daun pandan wangi. Nilai $\left(\mathrm{a}^{*}\right)$ menyatakan tingkat warna hijau sampai merah dengan kisaran -100 sampai +100 . Nilai rata-rata dari tingkat kemerahan $\left(a^{*}\right)$ dapat dilihat pada Tabel 6 .

Tabel 6. Nilai rata-rata tingkat kemerahan $\left(a^{*}\right)$ pada perlakuan perbandingan bahan dengan pelarutn dan lama ekstraksi.

\begin{tabular}{cccc}
\hline \multirow{2}{*}{$\begin{array}{c}\text { Perbandingan Bahan } \\
\text { dengan Pelarut }\end{array}$} & $24(\mathrm{~T} 1)$ & $36(\mathrm{~T} 2)$ & $48(\mathrm{~T} 3)$ \\
\cline { 2 - 4 } & $26,31 \pm 0,06^{\mathrm{a}}$ & $22,19 \pm 0,09^{\mathrm{c}}$ & $23,41 \pm 0,12^{\mathrm{b}}$ \\
$1: 13(\mathrm{P} 1)$ & $21,27 \pm 0,12^{\mathrm{d}}$ & $17,15 \pm 0,06^{\mathrm{g}}$ & $18,87 \pm 0,08^{\mathrm{e}}$ \\
$1: 15(\mathrm{P} 2)$ & $21,35 \pm 0,08^{\mathrm{d}}$ & $18,11 \pm 0,10^{\mathrm{f}}$ & $21,28 \pm 0,08^{\mathrm{d}}$ \\
$1: 17(\mathrm{P} 3)$ &
\end{tabular}

Keterangan: Huruf yang berbeda di belakang nilai menunjukkan adanya perbedaan yang sangat nyata (P $\leq 0,01)$. Data merupakan rata-rata dari dua kelompok percobaan.

Tabel 6 menunjukkan, pada perlakuan perbandingan bahan dengan pelarut $(1: 15)$ dan lama ekstraksi 36 jam menghasilkan tingkat kemerahan $\left(\mathrm{a}^{*}\right)$ yang paling rendah

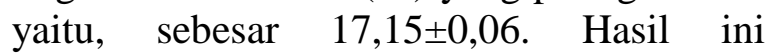
berhubungan dengan tingginya kandungan klorofil yang terdapat dalam ekstrak daun pandan wangi pada perbandingan bahan dengan pelarut (1:15) dengan lama maserasi 36 jam, sehingga semakin tinggi kandungan klorofil dalam ekstrak tersebut maka nilai tingkat kemerahan semakin rendah atau warna yang semakin hijau.

\section{Tingkat kekuningan (b*)}

Hasil analisis keragaman menunjukkan bahwa faktor perlakuan perbandingan bahan dengan pelarut, lama ekstraksi dan interaksi kedua perlakuan berpengaruh sangat nyata
$(\mathrm{P} \leq 0,01)$ terhadap tingkat kekuningan $\left(\mathrm{b}^{*}\right)$ ekstrak daun pandan wangi. Nilai $\left(b^{*}\right)$ menyatakan tingkat warna biru sampai kuning dengan kisaran -100 sampai +100 . Nilai rata-rata dari tingkat kemerahan $\left(\mathrm{L}^{*}\right)$ dapat dilihat pada Tabel 7.

Tabel 7 menunjukkan, pada perlakuan perbandingan bahan dengan pelarut (1:15) dan lama ekstraksi 36 jam menghasilkan intensitas warna $\left(b^{*}\right)$ tertinggi yaitu sebesar 30,43 , tetapi tidak berbeda nyata dengan perlakuan (1:15) dengan lama ekstraksi 24 jam dan (1:17) dengan lama ekstraksi 36 jam. Hal tersebut dikarenakan semakin tinggi pigmen krolofil $\mathrm{b}$ pada bahan maka tingkat kekuningan $\left(b^{*}\right)$ semakin meningkat. Semakin tinggi tingkat kekuningan maka menunjukkan kecenderungan warna yang 
semakin kuning.

Warna hijau kekuningan menurut Gross (1991) berasal dari komponen klorofil b. Klorofil merupakan senyawa yang sangat sensitif, klorofil akan sangat mudah terdegradasi pada paparan suhu tinggi dan cahaya, sehingga akan mengubah warnanya menjadi kekuningan (Du et al., 2014). Penelitian Zendrato et al. (2014) menyatakan bahwa warna ekstrak pada lamun yang diperoleh dengan proses ekstraksi menggunakan pelarut aseton cenderung berwarna hijau kekuningan.

Tabel 7. Nilai rata-rata tingkat kekuningan $\left(b^{*}\right)$ pada perlakuan perbandingan bahan dengan pelarutn dan lama ekstraksi.

\begin{tabular}{cccc}
\hline Perbandingan Bahan & \multicolumn{3}{c}{ Lama Ekstraksi (jam) } \\
\cline { 2 - 4 } dengan Pelarut & $24(\mathrm{~T} 1)$ & $36(\mathrm{~T} 2$ & $48(\mathrm{~T} 3)$ \\
\hline $1: 13(\mathrm{P} 1)$ & $24,27 \pm 0,13^{\mathrm{f}}$ & $26,67 \pm 0,18^{\mathrm{d}}$ & $25,66 \pm 0,57^{\mathrm{e}}$ \\
$1: 15(\mathrm{P} 2)$ & $29,73 \pm 0,30^{\mathrm{ab}}$ & $30,43 \pm 0,13^{\mathrm{a}}$ & $29,25 \pm 0,06^{\mathrm{bc}}$ \\
$1: 17(\mathrm{P} 3)$ & $28,37 \pm 0,06^{\mathrm{d}}$ & $29,62 \pm 0,13^{\mathrm{ab}}$ & $29,14 \pm 0,13^{\mathrm{bc}}$ \\
\hline
\end{tabular}

Keterangan: Huruf yang berbeda di belakang nilai rata-rata menunjukkan adanya perbedaan yang sangat nyata (P $\leq 0,01)$. Data merupakan rata-rata dari dua kelompok percobaan

\section{Uji indek efektivitas}

Penentuan perlakuan terbaik dalam menghasilkan ekstrak pewarna alami daun pandan wangi ditentukan berdasarkan metode indeks efektivitas (De Garmo et al., 1984). Hasil perhitungan uji indeks efektivitas dapat dilihat pada Tabel 8. Bobot variabel dari hasil kuisioner yang diurutkan menurut prioritas dan kontribusi terhadap hasil produk oleh para ahli dari parameter rendemen, kadar klorofil a, kadar klorofil b, kadar klorofil total tingkat kecerahan $\left(\mathrm{L}^{*}\right)$, tingkat kemerahan $\left(\mathrm{a}^{*}\right)$ dan tingkat kekuningan $\left(b^{*}\right)$.

Perlakuan terbaik ditunjukkan dengan jumlah nilai tertinggi. Tabel 8 menunjukkan bahwa perlakuan perbandingan bahan dengan pelarut dan lama ekstraksi mempunyai nilai tertinggi yaitu 1,00. Hal tersebut menunjukan bahwa perlakuan perbandingan bahan dengan pelarut dan lama maserasi 1:15 dan lama ekstraksi 36 jam merupakan perlakuan terbaik untuk menghasilkan ekstrak pewarna alami daun pandan wangi.

\section{KESIMPULAN DAN SARAN}

\section{Kesimpulan}

Berdasarkan hasil penelitian yang telah dilakukan dapat disimpulkan, antara lain :

1. Perlakuan perbandingan bahan dengan pelarut dan lama ekstraksi sangat berpengaruh terhadap rendemen ekstrak, kadar klorofil a, klorofil b, klorofil total, tingkat kecerahan $\mathrm{L}^{*}$, tingkat kemerahan $a^{*}$, tingkat kekuningan $b$, Interaksi antar perlakuan sangat berpengaruh terhadap kadar klorofil a, klorofil b, klorofil total, tingkat kemerahan $\left(\mathrm{a}^{*}\right)$, tingkat kekuningan $\quad\left(b^{*}\right)$ tetapi tidak berpengaruh terhadap rendemen ekstrak dan tingkat kecerahan $\left(\mathrm{L}^{*}\right)$.

2. Perlakuan perbandingan bahan dengan pelarut 1:15 dan lama ekstraksi 36 jam, merupakan perlakuan terbaik untuk menghasilkan ekstrak pewarna daun pandan wangi dengan karakteristik rendemen sebesar 10,32 \%, kadar klorofil a sebesar 3402,04 ppm, kadar klorofil b sebesar 612,23 ppm, kadar klorofil total sebesar 4013,42 ppm, tingkat kecerahan $\left(\mathrm{L}^{*}\right)$ 35,27, tingkat kemerahan $\left(\mathrm{a}^{*}\right) \quad 17,15$, tingkat kekuningan $\left(b^{*}\right) 30,43$.

\section{Saran}

Berdasarkan hasil penelitian, disarankan menggunakan perbandingan 
bahan dengan pelarut (1:15) dan lama ekstraksi 36 jam untuk menghasilkan ekstrak daun pandan wangi serta dilakukannya perlakuan lanjutan seperti enkapsulasi agar mendapatkan ekstrak pewarna yang dapat diaplikasikan ke dalam bahan pangan.

\section{DAFTAR PUSTAKA}

Aronoff, S. 1958. The Chemistry of Chlorophyll. Advance in Food Research IV, Canada.

Dalimartha, S. 1999. Atlas Tumbuhan Obat Jilid 1. Trubus Agriwidya, Jakarta.

De Garmo, E.P., Sullivan W.G and C.R. Canada. 1984. Engineering economy. $7^{\text {th }}$ edition. Mac. Millan publ Co, New York.

Du, L., X. Yang, J. Song, Z. Ma, Z. Zhang, and X. Pang. 2014. Characterization of the stage dependency of high temperature on green ripening reveals a distinct chlorophyll degradation regulation in banana fruit. Journal of Scientia Horticulturae. 180: 139 -146.

Gross, J. 1991. Pigments in Vegetable, Chlorophylls and Crotenoids. Van Nostrand Reinhold, New York.

Handayani. H., F. H. Sriherfyna dan Yunianta. 2016. Ekstraksi antiokasidan daun sirsak metoda ultrasonic batch (kajian rasio bahan : pelarut dan lama ekstraksi). Jurnal Pangan dan Agroindustri. 4 (1):262-272.

Hernes. I. P. F., L. Suhendra., dan L. P. Wrasiati. 2018. Pengaruh perbandingan bahan dengan pelarut aseton terhadap total fenolik, warna dan klorofil ekstrak Sargassum polycystum. Jurnal Rekayasa dan Manajemen Agroindustri. 6 (2):103-114.
Khuluq, A. D., S. B. Widjanarko dan E.S. Murtini. 2007. Ekstraksi dan betasianin daun darah (Alternanthera dentata) (kajian perbandingan pelarut air:etanol 1 dan suhu ekstraksi). Jurnal Teknologi Pertanian. 8(3): 172-181

Margaretta. S., S.D. Handayani dan N. Indraswati., H. Hindarso. 2011. Ekstraksi senyawa phenolic Pandanus amaryllifolius Roxb. sebagai antioksidan alami. Widya Teknik. 10 (1): (21-30).

Manasika, A., dan S.B. Widjanarko. 2015. Ekstraksi pigmen karotenoid labu kabocha menggunakan metode ultrasonik (kajian rasio bahan: pelarut dan lama ekstraksi). Jurnal Pangan dan Agroindustri. 3 (3):928-938.

Nollet, LML. 2004. Handbook of Food Analysis. Physical characterzati-ion and nutrient analysis. Marcel Dekker Incorporation, New York.

Sudarmadji, S., B. Haryono, dan Suhardi. 1989. Prosedur Analisa Untuk Bahan Makanan dan Pertanian. Liberty, Yogyakarta.

Putri. W. D. R., E. Zubaidah., N. Sholahudin. Ekstraksi pewarna alami daun suji, kajian pengaruh blanching dan jenis bahan pengekstrak. Jurnal Teknologi Pertanian. 4(1):13-24.

Pratista. I. M. I., L. Suhendra dan L. P Wrasiati. 2017. Karakteristik pewarna alami pada ekstrak Sargassum polycystum dengan konsentrasi pelarut etanol dan lama laserasi yang berbeda. Jurnal Rekayasa dan Manajemen Agroindustri. 5(4):51-60.

Reysa, E. 2013. Rahasia Mengetahui Makanan Berbahaya. Titik Media Publisher, Jakarta. 
Weaver, C. 1996. The Food chemistry laboratory. CRC Press, Boca Raton, New York, London, Tokyo.

Zendrato, I. A., F. Swatawati., dan Romadhon. 2014. Ekstraksi klorofil dan karotenoid dengan konsentrasi pelarut yang berbeda pada lamun (Enhalusacoroides) di perairan laut Jawa. Jurnal Pengolahan dan Bioteknologi Hasil Perikanan. 3 (1): 30-39.

Tabel 8. Uji indeks evektifitas ekstrak daun pandan wangi.

\begin{tabular}{|c|c|c|c|c|c|c|c|c|c|}
\hline Variabel & & Rendemen & $\begin{array}{c}\text { Klorofil } \\
\text { a }\end{array}$ & $\begin{array}{c}\text { Klorofil } \\
\text { b }\end{array}$ & $\begin{array}{c}\text { Klorofil } \\
\text { total }\end{array}$ & L* & a $^{*}$ & b* & Jumlah \\
\hline & (BV) & 3,60 & 5,60 & 5,00 & 5,80 & 3,00 & 4,20 & 3,80 & 28 \\
\hline & (BN) & $\mathbf{0 , 1 2}$ & $\mathbf{0 , 1 8}$ & $\mathbf{0 , 1 6}$ & $\mathbf{0 , 1 9}$ & $\mathbf{0 , 1 0}$ & $\mathbf{0 , 1 4}$ & $\mathbf{0 , 1 2}$ & $\mathbf{1 , 0 0}$ \\
\hline P1T1 & $\mathrm{Ne}$ & 0,00 & 0,06 & 0,19 & 0,07 & 0,00 & 0,00 & 0,00 & \\
\hline & $\mathrm{Nh}$ & 0,00 & 0,01 & 0,03 & 0,01 & 0,00 & 0,00 & 0,00 & 0,05 \\
\hline P1T2 & $\mathrm{Ne}$ & 0,32 & 0,40 & 0,35 & 0,38 & 0,69 & 0,45 & 0,39 & \\
\hline & $\mathrm{Nh}$ & 0,04 & 0,07 & 0,06 & 0,07 & 0,07 & 0,06 & 0,05 & 0,41 \\
\hline P1T3 & $\mathrm{Ne}$ & 0,18 & 0,00 & 0,12 & 0,00 & 0,14 & 0,32 & 0,23 & \\
\hline & $\mathrm{Nh}$ & 0,02 & 0,00 & 0,02 & 0,00 & 0,01 & 0,04 & 0,03 & 0,12 \\
\hline P2T1 & $\mathrm{Ne}$ & 0,62 & 0,80 & 0,68 & 0,77 & 0,45 & 0,55 & 0,89 & \\
\hline & $\mathrm{Nh}$ & 0,07 & 0,14 & 0,11 & 0,14 & 0,04 & 0,07 & 0,11 & 0,70 \\
\hline P2T2 & $\mathrm{Ne}$ & 1,00 & 1,00 & 1,00 & 1,00 & 1,00 & 1,00 & 1,00 & \\
\hline & $\mathrm{Nh}$ & 0,12 & 0,18 & 0,16 & 0,19 & 0,10 & 0,14 & 0,12 & $\mathbf{1 , 0 0}$ \\
\hline P2T3 & $\mathrm{Ne}$ & 0,43 & 0,64 & 0,90 & 0,69 & 0,86 & 0,81 & 0,81 & \\
\hline & $\mathrm{Nh}$ & 0,05 & 0,12 & 0,15 & 0,13 & 0,08 & 0,11 & 0,10 & 0,73 \\
\hline P3T1 & $\mathrm{Ne}$ & 0,43 & 0,51 & 0,00 & 0,39 & 0,18 & 0,54 & 0,66 & \\
\hline & $\mathrm{Nh}$ & 0,05 & 0,09 & 0,00 & 0,07 & 0,02 & 0,07 & 0,08 & 039 \\
\hline P3T2 & $\mathrm{Ne}$ & 0,83 & 0,73 & 0,53 & 0,68 & 0,50 & 0,90 & 0,87 & \\
\hline & $\mathrm{Nh}$ & 0,10 & 0,13 & 0,09 & 0,13 & 0,05 & 0,12 & 0,11 & 0,72 \\
\hline P3T3 & $\mathrm{Ne}$ & 0,73 & 0,38 & 0,33 & 0,35 & 0,22 & 0,55 & 0,79 & \\
\hline & $\mathrm{Nh}$ & 0,08 & 007 & 0,05 & 0,07 & 0,02 & 0,07 & 0,10 & 0,46 \\
\hline
\end{tabular}

Keterangan : $\mathrm{Ne}=$ Nilai efektifitas

$\mathrm{BV}=$ Bobot variabel

$\mathrm{Nh}=$ Nilai hasil $(\mathrm{Ne} \times \mathrm{BN})$

$\mathrm{BN}=$ Bobot normal 